\title{
Health promotion of lesbian woman: nursing care
}

Promoção da saúde da mulher lésbica: cuidados de enfermagem

Promoción de la salud de la mujer lesbiana: cuidados de enfermería GE Revista Gaúcha

\author{
Josueida de Carvalho Sousa ${ }^{a}$ \\ Danielli Gavião Mallmann ${ }^{b}$ \\ Nelson Miguel Galindo Netoc \\ Natália Oliveira de Freitas ${ }^{d}$ \\ Eliane Maria Ribeiro de Vasconcelos ${ }^{\mathrm{e}}$ \\ Ednaldo Cavalcante de Araújo ${ }^{f}$
}

\begin{abstract}
The aim of this study was to analyze national and international scientific literature on nursing care for lesbian women. An integrative approach was adopted to review studies from MEDLINE, LILACS, BDENF and SCOPUS databases and SciELO and Cochrane libraries using the keywords: female homosexuality, nursing care, health promotion and women's health. Studies published between 1990 and 2013 in English, Portuguese or Spanish were considered for analysis. After analyzing data, four international studies were selected, being that three were from the United States and one was from Canada. This study revealed a scarcity of Brazilian and international studies and the importance of increasing scientific literature on this topic.

Descriptors: Homosexuality, female. Nursing care. Health promotion. Women's health.
\end{abstract}

\section{RESUMO}

Objetivou-se analisar a produção científica nacional e internacional sobre a assistência de enfermagem à mulher lésbica. Realizou-se revisão integrativa a partir da busca de estudos nas bases MEDLINE, LILACS, BDENF e SCOPUS, nas bibliotecas SciELO e COCHRANE, utilizando os descritores: homossexualidade feminina, cuidados de enfermagem, promoção da saúde e saúde da mulher. Selecionaram-se estudos publicados no período de 1990 a 2013, nos idiomas inglês, português ou espanhol. Após a análise dos dados, foram selecionados quatro estudos em âmbito internacional, dos quais três eram dos Estados Unidos e um do Canadá. Este estudo evidenciou a escassez de estudos brasileiros e internacionais, traduzindo-se na importância de incrementar a produção cientíica relacionada ao tema em estudo.

Descritores: Homossexualidade feminina. Cuidados de enfermagem. Promoção da saúde. Saúde da mulher.

\section{RESUMEN}

Este estudio tuvo como objetivo analizar la literatura científica nacional e internacional en la atención de enfermería a las lesbianas. Revisión integradora se realizó a partir de la búsqueda de los estudios en MEDLINE, LILACS, BDENF, SCOPUS y bibliotecas SciELO y Cochrane usando las palabras clave: homosexualidad femenina, atención de enfermería, promoción de la salud y salud de la mujer. Se seleccionaron los estudios publicados desde 1990 hasta 2013 en inglés, portugués o español. Después de analizar los datos se seleccionaron cuatro estudios a nivel internacional, de los cuales tres eran de los Estados Unidos y uno de Canadá. Este estudio demostró una falta de estudios brasileños e internacionales, que se refleja en la importancia de aumentar la producción científica relacionada con el tema objeto de estudio.

Descriptores: Homosexualidad femenina. Atención de enfermería. Promoción de la salud. Salud de la mujer.
DOl: $\quad$ http://dx.doi.org/10.1590/1983-

1447.2014.04.45308

a Nurse. Master's degree student in Nursing from the Universidade Federal de Pernambuco (UFPE). Substitute Professor of the Department of Nursing at the Universidade Federal de Pernambuco (UFPE). RecifePernambuco (PE). Brazil.

${ }^{b}$ Nurse. Master's degree student in Nursing from the Universidade Federal de Pernambuco (UFPE). RecifePernambuco (PE). Brazil.

Nurse. Master's degree student in Nursing from the Universidade Federal de Pernambuco (UFPE). Professor of the Bachellor degree in Nursing programme of the Instituto Federal de Educação, Ciência e Tecnologia de Pernambuco - Campus Pesqueira (IFPE). Pesqueira-Pernambuco (PE). Brazil.

${ }^{d}$ Nurse. Master's degree student in Nursing from the Universidade Federal de Pernambuco (UFPE). RecifePernambuco (PE). Brazil.

e Nurse. Doctoral degree student in Nursing. Adjunct Professor of the Department of Nursing at the Universidade Federal de Pernambuco (UFPE). RecifePernambuco (PE). Brazil.

N Nurse. PhD in Nursing. Adjunct Professor of the Department of Nursing at the Universidade Federal de Pernambuco (UFPE). Recife-Pernambuco (PE). Brazil. 


\section{DINTRODUCTION}

Some topics, such as the concept of "lesbian" used to describe a woman who are attracted to people of the same sex, are viewed with prejudice and considered taboo by society and are rarely discussed to prevent their influence on human behaviour (1).

Studies conducted in the United States of America on female homosexuality largely show a high morbidity rate among this population, typically due to breast and cervical cancer and obesity. Factors that contribute to this condition are alcoholism, drug abuse, non-use of healthcare services and the fragility of healthcare that focuses on lesbians ${ }^{(2)}$.

In Brazil, studies on female homosexuality are scarse, considering that birth control policies only started to be discussed in the 1970s and political and cultural conditions that enabled studies on women's reproductive issues were only created in the 1980s. Studies on female homosexuality and related healthcare were sidelined, following research on female sexuality that discussed the construction of identities, sociability and conjugality, and the vulnerability and invisibility of this population ${ }^{(2)}$.

Universal and equal access to comprehensive healthcare is assured by the Unified Health System (SUS), although evidence shows that care provided by health providers is inadequate. This reveals the need to readapt health services and better prepare professionals to provide care that observes sexuality and the ability to establish a bond with users. The practices of healthcare providers are marked by prejudice and taboo, especially in relation to female homosexuality, which reveals the difficulty in approaching this topic ${ }^{(3)}$.

Assistance for homosexual women is often fragmented and decontextualized because it does not observe their sexual orientation and they are attended as heterosexuals. Care for these women should be culturally adapted to their values and lifestyle, which would justify the use of specific techniques and skills during interviews to ensure adequate anamnesis and guidelines ${ }^{(3-4)}$.

Although the body of a homosexual woman is similar to the body of women of other sexual orientations, access to comprehensive care is not similar, as the quality of care depends on the relationship between professionals and users. Prejudice therefore obstructs the comprehension and impartiality that are required for reviewing empirical studies, suggesting that a significant number of healthcare professionals feel uncomfortable when providing care to homosexuals ${ }^{(4-5)}$

Research shows that after a lesbian manifests her sexual orientation, healthcare professionals shorten the consulta- tion or do not request tests, which can compromise care. Furthermore, this suggests that lesbians are less likely to receive routine care, such as gynaecological tests, which can increase the risk of breast and endometrial cancer due to a high incidence of nulliparity ${ }^{(6-7)}$.

Nurses should be mindful of their own prejudice that can hinder quality care provided to certain populations, especially within the context of this study, that is, lesbian women. The guiding question of this study was: What is the panorama of national and international scientific production on nursing care for homosexual women? The aim was to analyse national and international scientific literature on nursing care for lesbian women.

\section{METHODOLOGY}

An integrative review approach was adopted, in which scientific literature is surveyed in a concise, ordered manner to provide updated knowledge on the studied topic. This research method provides healthcare professionals with important data on a given subject in different places and moments, keeps them updated, facilitates changes to clinical practices, and enables the implementation of interventions and cost reduction ${ }^{(8)}$.

In order to review literature, the following study stages were observed: 1) Identification of the guiding question; 2) Establishment of inclusion and exclusion criteria; 3) Study categorization; 4) Evaluation of the included studies; 5) Interpretation of results and; 6) Review presentation ${ }^{(8)}$.

Data were collected from September to November 2013 by means of online searches of articles that could answer the following research question: What is the panorama of national and international scientific production on nursing care for homosexual women?

Data were mapped by peers from the following databases: Medical Literature Analysis and Retrieval System Online (MEDLINE), Literatura Latino Americana e do Caribe em Ciências da Saúde (LILACS), Bases de Dados em Enfermagem (BDENF) and Scopus, and from online libraries Scientific Electronic Library Online (SciELO) and Cochrane.

The descriptors used in this study, indexed in the Health Sciences Descriptors (DeCS), were female homosexuality, nursing care, health promotion and women's health, with their corresponding English and Spanish translations. Inclusion criterion was publications from 1990 to 2013, in English, Portuguese or Spanish. Exclusion criterion was studies without abstracts available for analysis in the surveyed databases and libraries. The studies search process is shown in Figure 1. 


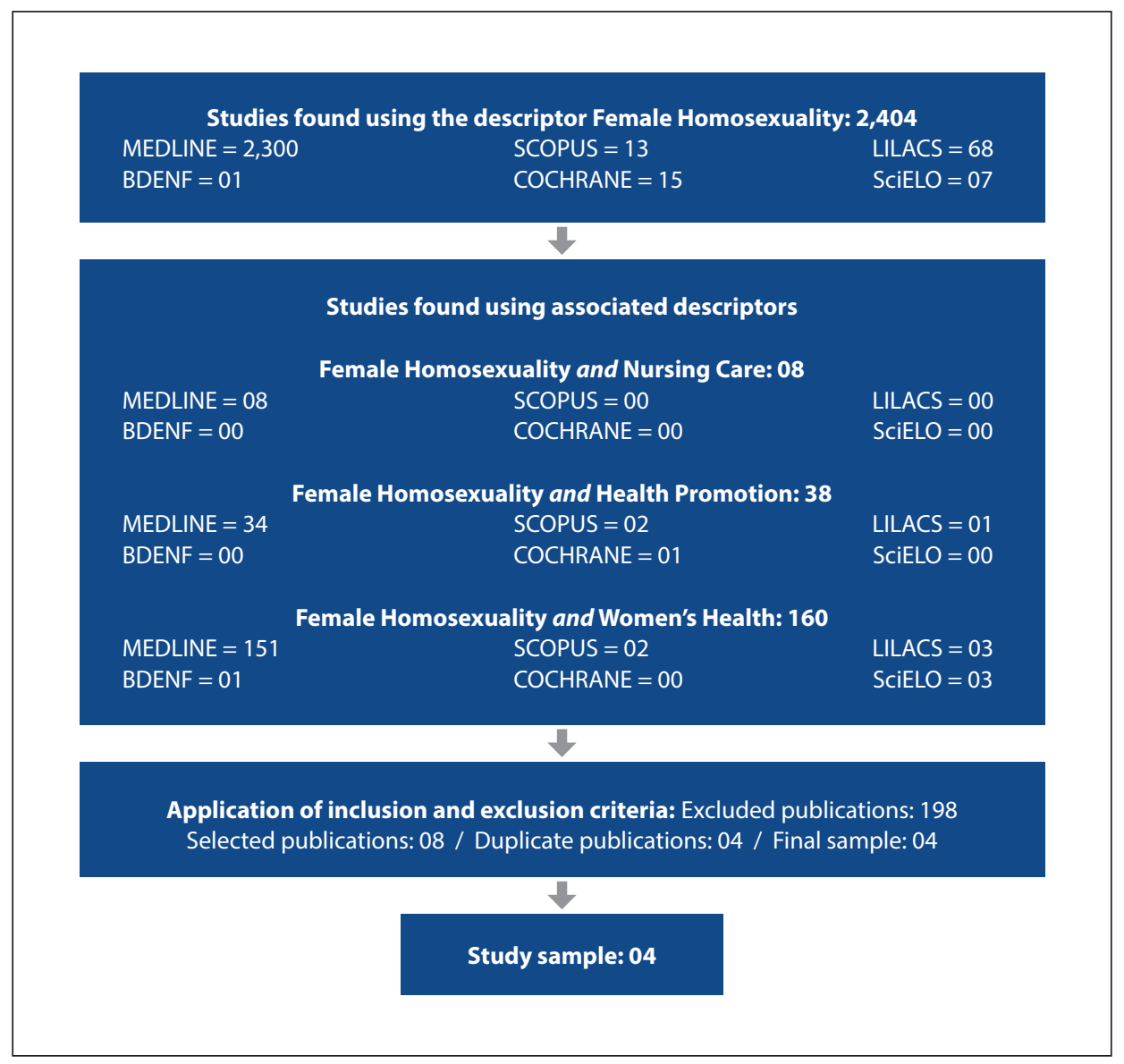

Figure 1. Flowchart of the study selection process. Recife, PE, Brazil 2014 Source: Research data, 2014.

Data were collected using a validated form ${ }^{(9)}$ with information on the professional category of the authors, research location and year, type of journal, title, type of study and level of scientific evidence. Information was extracted by reading and re-reading the publications, which were organized for data analysis. The methodologies of each study were analysed by classifying levels of evidence into six levels: I) meta-analysis of multiple controlled studies; II) individual experimental study; III) quasi-experimental study; IV) non-experimental study with descriptive correlational and qualitative research or case studies; $V$ ) case reports or data obtained systematically of verifiable quality or programme evaluation data; VI) the opinion of respectable authorities based on clinical competency or the opinion of committees of specialists ${ }^{(10)}$.

\section{RESULTS}

Results were based on four publications shown in Chart 1. The studies were in English, being that two were reflections and two were bibliographical reviews. In terms of the strength of evidence, the four articles obtained level IV. In relation to professional category, research was conducted by nurses with PhDs and Master's degrees who worked as professors or researchers, and there was no scientific production from students.

\section{DISCUSSION}

The database search produced few studies on the investigated topic. The national study search did not produce any studies on lesbians and nursing care. Of the four selected studies, three were from the USA and one was from Canada, which shows the need for national research to support related strategies for homosexual women.

In relation to professional category, studies conducted by scholars and professionals with experience on providing care are considered important to help bridge the gap between practical and scientific perspectives, resulting in accurate and relevant scientific production ${ }^{(11-14)}$. 


\begin{tabular}{|c|c|c|}
\hline $\begin{array}{l}\text { Authors and } \\
\text { Year }\end{array}$ & Objetive(s) & Key results \\
\hline Walpin (1997)11 & $\begin{array}{l}\text { Present the current state of knowledge on } \\
\text { formation of the individual identity and } \\
\text { development of a couple in the gay and } \\
\text { lesbian community and describe the impact of } \\
\text { heterosexism on the planning of nursing care. }\end{array}$ & $\begin{array}{l}\text { Heterosexism standardizes the assumption that society } \\
\text { is heterosexual, causing suffering among gays and } \\
\text { lesbians when they reveal their orientation to healthcare } \\
\text { professionals, which negatively compromises the } \\
\text { planning and provision of nursing care. }\end{array}$ \\
\hline $\begin{array}{l}\text { McDonald, } \\
\text { Mclntyre, } \\
\text { Anderson } \\
(2003)^{12}\end{array}$ & $\begin{array}{l}\text { Understand the experience of revealing } \\
\text { lesbianism and the contribution to women's } \\
\text { health for nursing education. }\end{array}$ & $\begin{array}{l}\text { Nurses should have a greater understanding and } \\
\text { awareness of the power structures in the health } \\
\text { system to create opportunities for lesbians to become } \\
\text { the subjects of their own lives and of their healthcare. }\end{array}$ \\
\hline $\begin{array}{l}\text { Dibble, } \\
\text { Eliason, } \\
\text { Christiansen } \\
(2007)^{13}\end{array}$ & $\begin{array}{l}\text { Discuss important definitions that describe } \\
\text { the lives of Lesbians, Gays and Bisexuals (LGB), } \\
\text { divulge sexual identities, risk factors and data } \\
\text { on chronic disease issues to LGB patients, and } \\
\text { how nurses can conduct vital assessments on } \\
\text { sexuality. }\end{array}$ & $\begin{array}{l}\text { There is a higher percentage of chronic diseases } \\
\text { among LGB groups than among heterosexuals. } \\
\text { Nurses should construct a new outlook on the topic } \\
\text { of gender and sexuality to provide equal care to all } \\
\text { groups. }\end{array}$ \\
\hline Weisz $(2008)^{14}$ & $\begin{array}{l}\text { Reflect on social justice for the healthcare of } \\
\text { lesbian and bisexual women. }\end{array}$ & $\begin{array}{l}\text { Healthcare for lesbian and bisexual women is subjected } \\
\text { to discrimination and requires awareness to ensure } \\
\text { social justice. Nurses are trained to listen to and provide } \\
\text { care to marginalized groups, and are in a unique } \\
\text { position to defend lesbians and bisexual women. }\end{array}$ \\
\hline
\end{tabular}

Chart 1. Publications selected for review. Recife, PE, Brazil 2014. Source: Research data, 2014.

The absence of Brazilian studies on this topic may be connected to the fact that female homosexuality is a recent theme in the Brazilian political agenda. It was only in 2003, after the $5^{\text {th }}$ Lesbian Women's Seminar, that it was acknowledged that public policies should observe lesbians in women's healthcare actions ${ }^{(15)}$.

In terms of the reduced number of publications and evidence levels, this study revealed a knowledge gap in relation to the published data that could otherwise validate healthcare and consider the diversity of the homosexual female population, with their desires, practices and/or identities.

Taboos and prejudice in relation to sex and reproduction, based on the conceptions of gender and sexuality, have been an impediment to quality comprehensive care for lesbian women ${ }^{(16)}$. The World Health Organization (WHO) has identified priority actions for healthcare services with gender equity and reproductive rights ${ }^{(14)}$ and, in Brazil, the Ministry of Health is gradually including the LGBT population in its public health policies, namely Brasil sem Homofobia (Homophobic-free Brazil): Programa de Combate à Violência e Discriminação contra GLTB e de Promoção da cidadania Homossexual (Programme for the fight against violence and discrimination against LGBT and the Promotion of homosexual citizenship), created in 2004 and the Politica Nacional de Saúde Integral Lésbicas, Gays, Bissexuais, Travestis e Transexuais (National Comprehensive Care Policy for Lesbians, Gays, Bisexuals, Transvestites and Transsexuals), of $2011^{(17)}$. Regardless, it has been observed that nurses provide care as if all users were heterosexual ${ }^{(11)}$.

Fears related to the prejudice and its effect on the lives and social relationships of this population lead to silence on homoerotic practices and desires and restrictions that could negatively impact their emotional experiences. Individual invisibility contributes to the individual vulnerability and social invisibility of these women, which, in turn, hinders the observance of public policies and programmes that meet their needs, subsequently reinforcing their social and individual vulnerability. This is the basis of omissions of health professionals during the provision of care ${ }^{(18)}$.

Heterosexism is defined as the belief that the world is heterosexual and that any other sexual orientation is considered inacceptable ${ }^{(14)}$. This can be more easily understood when the established norm is that gender or sexual identifies are defined by social relationships that, in turn, define heterosexuality as normal and marginalize homo- 
sexual relationships ${ }^{(19)}$. This attitude has an impact on interventions that could otherwise be favourable to this group, due to deep-rooted beliefs on the role of nurses when discussing sexuality and the transmission of the nurse's beliefs and values to the user in a discriminatory manner ${ }^{(14)}$.

When discussing sexuality, it is difficult for nurses to provide orientation on sexual practices even with heterosexual patients. On the other hand, sexuality has been specifically discussed by sexologists, which grants a normative nature to the topic that is chiefly marked by biological aspects, without approaching the topic of health that is not connected to reproduction ${ }^{(20)}$.

It should be noted that lesbian impressions on the care provided by health professionals include episodes of negligence, discrimination and harassment, leading them to believe that their life experiences are misunderstood by these professionals. Furthermore, lesbian women stated that when they sought healthcare services for cytopathology tests and revealed the number of partners, nurses expressed disgust, which was embarrassing for them ${ }^{(11)}$.

One study revealed that this population presents significant exposure to chronic diseases and that chronic disease notification rates are higher in homosexual populations. Among heterosexual women, these rates reach 70\%, whereas among lesbian women, they reach $80 \%$, especially for cardiovascular diseases, lung cancer and breast cancer, all associated to smoking. Other factors are alcoholism and drug abuse for cardiovascular diseases, which have a greater incidence, and nulliparity and alcoholism for breast cancer ${ }^{(12)}$.

This high incidence of diseases in the female homosexual population emphasizes the lack of health assistance for this group. Many times, professionals are confronted with prejudice and preconceptions with regard to female homosexuality, which hinders the provision of quality care due to the information brought by users, leading to the assumption that cytopathology tests and breast examinations are unnecessary although lesbians are more prone to breast and endometrial cancer ${ }^{(12)}$. Incidentally, the Federal Constitution of 1988 states that the right to health is a social right based on promoting well-being without prejudice and discrimination (20).

Considerations related to the importance of nurses, their training and contributions made available to lesbians are relevant, given that nurses' training comprises grounded theories that enable the provision of care that observes diversity, culture and religion. Consequently, nursing practice ethics involve knowing how to listen and understand the anguish of those considered marginalized and unknown due to an unacceptable diversity ${ }^{(14)}$. Based on this conception, healthcare services are characterized as being a scenario in which nurses provide assistance that focuses on women's health.

Nurses can create a welcoming environment through dialogue that includes beliefs, concerns and orientations on sexuality. However, nurses must be familiar with the needs of lesbians to deconstruct their ideologies and myths concerning this group ${ }^{(12)}$. In the scope of health services, it is essential to guarantee the inclusion of lesbians in all care scenarios to ensure their civil rights and freedom of sexual orientation, and effective health promotion actions.

\section{CONCLUSION}

Results showed that the relevance of nursing care for lesbian women was not being investigated in scientific research, considering that work on this topic was incipient during the study period. These scientific loopholes determine the need for public policies that ensure and evaluate care provided to this population.

As research was based on reflection studies that converge to trigger criticality and awareness on this topic, and to provoke unease in the academic community, conceptions on homosexuality still merge with the concepts of heterosexism and the difficulty of nurses in approaching the subject of sexuality, which compromises assistance and deprives lesbians of their rights. Consequently, the experiences of lesbians must be divulged for healthcare professionals to become familiar with the needs of this population and understand and modify the way they provide care.

Additional studies on this subject are therefore necessary to increase scientific evidence and consolidate references for professional practices and existing public policies. Nurses must also learn to abolish prejudice to enable comprehensive and equalitarian care.

\section{REFERENCES}

1. Toledo LG, Teixeira Filho FS. Lesbianidades e as referências legitimadoras da sexualidade. Estud Pesqui Psicol. 2010;10(3):729-49.

2. Barbosa RM, Koyama MAH. Mulheres que fazem sexo com mulheres: algumas estimativas para o Brasil. Cad Saúde Pública. 2006;22(7):1511-4.

3. Araújo MAL, Galvão MTG, Saraiva MMM, Albuquerque AD. Relação usuária-profissional de saúde: experiência de uma mulher homossexual em uma unidade de saúde de referência de Fortaleza. Esc Anna Nery Rev Enferm. 2006;10(2):323-7.

4. Barbosa RM, Facchini R. Acesso a cuidados relativos à saúde sexual entre mulheres que fazem sexo com mulheres. Cad Saúde Pública. 2009;25(Supl 2):291-300.

5. Santos ML, Murai HC. Homossexualismo feminino: um novo contexto para 0 trabalho humanizado na enfermagem. Rev Enferm UNISA. 2011;12(1):48-51.

6. Facchini R, Barbosa R. Dossiê Saúde das Mulheres Lésbicas: promoção da equidade e da integralidade. Belo Horizonte: Rede Feminista de Saúde; 2006. 
7. Valadão RC, Gomes R. A homossexualidade feminina no campo da saúde: da invisibilidade à violência. Physis. 2011;21(4):1451-67.

8. Mendes KDS, Silveira RCCP, Galvão CM. Revisão integrativa: método de pesquisa para a incorporação de evidências na saúde e na enfermagem. Texto Contexto Enferm. 2008;17(4):758-64.

9. Ursi ES, Galvão CM. Prevenção de lesão de pele no período perioperatório: revisão integrativa da literatura. Rev Latino-am Enfermagem. 2006;14(1):124-31.

10. Stetler CB, Morsi D, Rucki S, Broughton S, Corrigan B, Fitzgerald J, et al. Utilization-focused integrative reviews in a nursing service. Appl Nurs Res. 1998;11(4):195-206.

11. Walpin L. Combating heterosexism: implications for nursing. Clin Nurse Spec. 1997;11(3):126-32.

12. McDonald C, Mclntyre M, Anderson B. The view from somewhere: locating lesbian experience in women's health. Health Care Women Int. 2003;24(8):697-711.

13. Dibble SL, Eliason MJ, Christiansen MA. Chronic illness care for lesbian, gay, \& bisexual individuals. Nurs Clin North America. 2008:42(4):655-74.

14. Weisz VK. Social justice considerations for lesbian and bisexual women's health care. J Obstet Gynecol Neonatal Nurs. 2009;38(1):81-7.

\section{Author's address:}

Josueida de Carvalho Sousa

Rua Conde de Irajá, 937, Torre

50710-310, Recife, PE

E-mail: josueidacarvalhoo@yahoo.com.br
15. Avila MB. Direitos sexuais e reprodutivos: desafios para políticas de saúde. Cad Saúde Pública. 2006;19(Supl 2):465-9.

16. Almeida GES. Da invisibilidade à vulnerabilidade: percursos do 'corpo lésbico' na cena pública face à possibilidade de infecção por DST e AIDS [tese]. Rio de Janeiro: Instituto de Medicina Social, Universidade Estadual do Rio de Janeiro; 2005.

17. Ministério da Saúde (BR), Secretaria de Gestão Estratégica e Participativa, Departamento de Apoio à Gestão Participativa. Política nacional de saúde integral de lésbicas, gays, bissexuais, travestis e transexuais. Brasília: Ministério da Saúde; 2013.

18. Lionço T. Que direito à saúde para populaçãa LGBT? considerando direitos humanos, sexuais e reprodutivos, em busca da integralidade e equidade. Saúde Soc. 2008; 17(2);11-21.

19. Tiefer L. Uma perspectiva feminista sobre sexologia e sexualidade. In: Gerden MMC. 0 pensamento feminista e a estrutura do conhecimento. Rio de Janeiro: Rosa dos Tempos, Editora da UNB; 1988. p. 37-47.

20. Brasil. Constituição (1988). Constituição da República Federativa do Brasil. Moraes, A, organizador. 16. ed. São Paulo: Atlas, 2000.
Received: 27.02.2014

Approved: 05.12.2014 